\title{
Prevalence of Sexually Transmitted Diseases in Female Sex Workers in a City in the Interior of São Paulo, Brazil' ${ }^{1}$
}

\author{
Maíra Rodrigues Baldin-Dal Pogetto \\ Márcia Guimarães Silva ${ }^{3}$ \\ Cristina Maria Garcia de Lima Parada ${ }^{4}$
}

\begin{abstract}
Changes in the profile of sexually transmitted diseases have increased the need for their detection, particularly where there is a concentration of individuals with risk behavior, so that diagnosis and immediate treatment can be translated in the reduction of resulting problems. The objective was to identify the prevalence of sexually transmitted diseases in female sex workers in a medium-sized city in São Paulo state. This population prevalence study was conducted in 2008 on 102 females. The prevalence was $71.6 \%$. When considered separately and in association, the highest values found were: HPV (67.7\%) and Chlamydia (20.5\%). HPV typing showed oncogenic genotypes. The prevalence of syphilis was $4.0 \%$ and of trichomoniasis $3.0 \%$. No cases of hepatitis $B$ or gonorrhea were identified. It was concluded that the prevalence of sexually transmitted diseases in the studied group was high, since approximately two thirds of the women showed some type of disease under this classification.
\end{abstract}

Descriptors: Infection; Women's Health; Prevalence; Nursing.

\footnotetext{
1 Paper extracted from Master's Dissertation "Prevalência de Doenças Sexualmente Transmissíveis em Mulheres Profissionais do Sexo do Município de Botucatu, São Paulo" presented to Nursing Undergraduate Program, Faculdade de Medicina de Botucatu, Universidade Estadual Paulista "Júlio de Mesquita Filho". Supported by Fundação de Amparo à Pesquisa do Estado de São Paulo (FAPESP), process \# 2008/58177-5, and Secretaria de Estado da Saúde de São Paulo.

${ }^{2}$ RN, Secretaria Municipal de Saúde de Botucatu, SP, Brazil. Master Student, Faculdade de Medicina de Botucatu, Universidade Estadual Paulista "Júlio de Mesquita Filho", SP, Brazil. E-mail: mairabaldin@yahoo.com.br.

${ }^{3}$ Biologist, Ph.D. in Pathology, Assistant Professor, Faculdade de Medicina de Botucatu, Universidade Estadual Paulista "Júlio de Mesquita Filho", SP, Brazil. E-mail: mgsilva@fmb.unesp.br.

${ }^{4}$ RN, Free Lecture, Adjunct Professor, Faculdade de Medicina de Botucatu, Universidade Estadual Paulista "Júlio de Mesquita Filho", SP, Brasil. E-mail: cparada@fmb.unesp.br.
}

Corresponding Author:

Cristina Maria Garcia de Lima Parada

UNESP. Faculdade de Medicina de Botucatu. Departamento de Enfermagem

Campus Universitário Rubião Júnior, $\mathrm{s} / \mathrm{n}$.

CEP: 18618-970, Botucatu, SP, Brasil.

E-mail: cparada@fmb.unesp.br 


\title{
Prevalência de doenças sexualmente transmissíveis em mulheres profissionais do sexo, em um município do interior paulista, Brasil
}

Mudanças no perfil das doenças sexualmente transmissíveis têm ampliado a necessidade de seu rastreamento, especialmente onde existe concentração de pessoas ou grupos com comportamentos de risco, para que o diagnóstico e tratamento imediato se traduzam na redução dos problemas causados. Objetivou-se identificar a prevalência de doença sexualmente transmissível entre mulheres profissionais do sexo, de município de médio porte do interior paulista. Este estudo de prevalência populacional foi realizado no ano 2008 com 102 profissionais do sexo. A prevalência geral de doença sexualmente transmissível foi $71,6 \%$. Considerados isoladamente e em associação, os maiores valores encontrados foram: HPV $(67,7 \%)$ e infecção clamidiana (20,5\%). A tipagem do HPV evidenciou genótipos oncogênicos. A prevalência de sífilis foi de $4,0 \%$ e de tricomoníase $3,0 \%$. Nenhum caso de hepatite B ou gonorreia foi identificado. Conclui-se que a prevalência de doença sexualmente transmissível foi elevada, pois, aproximadamente dois terços das mulheres, apresentavam alguma doença assim classificada.

Descritores: Infecção; Saúde da Mulher; Prevalência; Enfermagem.

\section{Prevalencia de enfermedades sexualmente transmisibles en mujeres profesionales del sexo en un municipio del interior del estado de Sao Paulo, Brasil}

\begin{abstract}
Cambios en el perfil de las enfermedades sexualmente transmisibles han ampliando la necesidad de su seguimiento, especialmente donde existe concentración de personas o grupos con comportamientos de riesgo, para que el diagnóstico y tratamiento inmediato se traduzcan en reducción de los problemas causados. El objetivo fue identificar la prevalencia de enfermedad sexualmente transmisible entre mujeres profesionales del sexo de un municipio de porte medio del interior del estado de Sao Paulo. Este estudio de prevalencia poblacional fue realizado en el año de 2008 con 102 profesionales del sexo. La prevalencia general de enfermedad sexualmente transmisible fue $71,6 \%$. Considerados aisladamente y en asociación, los mayores valores encontrados fueron: VPH $(67,7 \%)$ e infección clamidiana $(20,5 \%)$. El tipaje del VPH evidenció genotipos oncogénicos. La prevalencia de sífilis fue de 4,0\% y de tricomoníasis 3,0\%. Ningún caso de hepatitis $B$ o gonorrea fue identificado. Se concluye que la prevalencia de enfermedad sexualmente transmisible fue elevada, ya que aproximadamente dos tercios de las mujeres presentaban alguna enfermedad de ese tipo.
\end{abstract}

Descriptores: Infección; Salud de la Mujer; Prevalencia; Enfermería.

\section{Introduction}

Sexually Transmitted Diseases (STD) should be prioritized as public health problems. Interrupting the transmission chain and preventing new events are considered basic actions ${ }^{(1)}$. The World Health Organization (WHO) estimates that, in Brazil, every year, about 12 million cases of STD occur ${ }^{(2)}$. Undernotification remains high, bordering on 200 thousand cases per year, especially due to the search for alternative cures, as $70 \%$ of victims do not directly turn to health services(3). Historically, the health system has not incorporated care delivery to the most vulnerable populations, such as sex workers (SW), characterized as hard to access and having very particular needs. However, through the increase in STD/aids prevention actions, care delivery to 
these groups has increased, with strong stimuli for them to seek health services ${ }^{(4)}$. Different interventions aimed at SW, associating STD diagnosis and treatment with condom use promotion, are ongoing in developing countries and have proved their efficacy to decrease the incidence of the human immunodeficiency virus (HIV)/aids and/or other STD ${ }^{(5)}$. To reduce risk and vulnerability situations, however, women need to be considered active subjects. Health services are responsible for seeking strategies to enhance the adoption of protective behaviors. It is important to highlight that risk perception should not only be seen individually, but also in a social and cultural context, clearly influencing preventive actions ${ }^{(6)}$.

The international success of the Brazilian response to cope with HIV/aids and other STD has been acknowledged, due to the policy of universal access to prevention, diagnosis and treatment and to the quality of available information, mainly of studies and research in different knowledge areas, evidencing support to different governmental strategies in this field, which shows to be extremely relevant. Health professionals who do research on-the-job produce a significant part of this new knowledge, resulting in innovative products and processes of interest to the Unified Health System $(\mathrm{SUS})^{(7)}$.

The National STD/aids Program, in the context of the epidemic, includes SW as one of the groups with specific needs that should be attended to. It is worth highlighting that actions involving this population, in combination with the research performed, have contributed to further knowledge on the reality of female prostitution in Brazil( ${ }^{(8)}$. Therefore, this study was proposed to identify the prevalence of STD among sex workers from a medium-sized city in the interior of São Paulo State.

\section{Method}

\section{Study design and place of study}

This epidemiological population-based research aimed to identify the prevalence of STD in the female population of sex workers in Botucatu/SP, a city located in the central region of São Paulo State, where the municipal STD/aids program was set up in 2002. The work team in this program comprises one coordinator and four strategic prevention agents. As proposed at state level, the city attempts to accomplish actions to decrease the population's vulnerability to STD//HIV/aids, improve victims' quality of life and reduce the prejudice, discrimination and other negative social impacts of STD/
HIV/aids, through public policies guided by ethics and commitment to health promotion and citizenship, in line with SUS principles.

\section{Study population}

The study population is considered floating, as relocations are frequent. Therefore, two criteria were adopted to identify the study group: definition of the data collection period, between August 2008 and March 2009, and accomplishment of at least three visits to each of the six sites where the women stayed and worked. One hundred and seven SW were identified, $102(95.3 \%)$ of whom actually participated in the study, as five $(4.7 \%)$ moved before data collection.

\section{Characterization of study population}

To characterize the SW, an instrument was used, constructed specifically for the study. The following information was obtained: age (years); years of education; marital status (married, single, fixed partner, other) and age of first sexual intercourse (years).

\section{Vaginal contents, cervical secretion and blood collection}

Vaginal contents, cervical secretion and blood were collected at the sites where the SW practiced their profession, i.e. at one of the six houses where they received their clients. Initially, space was requested to set up the collection room, with a gynecological table and all material needed for the procedures.

Next, the SW were invited to participate in the study, without any refusal. Next, pretest STD/aids counseling was provided and four previously trained strategic STD/ aids Program agents interviewed the participants to collect data on the women's characteristics, guaranteeing their privacy and anonymity. Information the strategic agents obtained was considered more reliable, due to their bond with the SW.

After the interview, the women were forwarded for peripheral blood collection, through venipuncture. The material was stored in sterile Vacutainer (Beckton Dickinson, Rutherford, NJ, USA) test tubes. Next, the blood samples collected to diagnose syphilis and Hepatitis B were forwarded to the Clinical Laboratory, while samples for HIV diagnosis were forwarded to the Hemocentro of the Botucatu Medical School Hospital das Clínicas.

After the blood collection, the SW was forwarded for a gynecological exam, performed by one of the authors, 
who is a nurse and responsible for the Municipal STD/ aids Program. A sterilized, disposable Collins bi-valve speculum was used without any lubricant. Next, using an Ayre spatula, contents were collected from the bottom of the vaginal sack, seeded in liquid Diamonds medium to examine Trichomonas vaginalis (TV). The collected material was kept between 36 and $37^{\circ} \mathrm{C}$ until reaching the Human Reproduction Immunology Laboratory of the Pathology Department at Botucatu Medical School, Universidade Estadual Paulista, where it was stored in a hothouse at $37^{\circ} \mathrm{C}$.

Cervical secretion to examine Chlamydia trachomatis (CT), Neisseria gonorroheae (NG) and Human Papillomavirus (HPV) was collected with a cytobrush. The material collected to examine CT and HPV was placed in a $15 \mathrm{~mL}$ Falcon tube with $1000 \mu \mathrm{L}$ of Tris- $\mathrm{HCl} 50 \mathrm{mM} \mathrm{pH} 8.5$ / EDTA $1 \mathrm{mM} \mathrm{pH} 8.0$ (TE) solution and stored at $-20^{\circ} \mathrm{C}$ until its processing at the same Laboratory. Presence of CT in cervical secretion was assessed through the Polymerase Chain Reaction (PCR) technique. For HPV, PCR and PCR multiplex typing were used. To examine NG, cervical secretion was seeded in Thayer Martin medium. Plates were stored in an anaerobiosis jar and forwarded for processing at the Bacteriology Laboratory of the Microbiology and Immunology Department, Botucatu Institute of Biosciences, Universidade Estadual Paulista.

The researcher who performed the gynecological exams transported all collected material three hours after the collection at most, at the end of the activities.

\section{Diagnostic criteria for tests performed}

Sexually transmitted diseases (STD): hepatitis B (reagent, non reagent), syphilis (reagent, non reagent), anti-HIV (reagent, non reagent), CT (positive, negative), TV (positive, negative), NG (positive, negative), HPV (positive, negative), genotypes in case of positive HPV $(6 / 11,16,18,33$ and 45$)$.

\section{Data analysis}

For data analysis, a database was created in Excel, which was then analyzed using Epiinfo statistical software.

\section{Ethical procedures}

Approval for this study was obtained from the Institutional Review Board at Botucatu Medical School. All guidelines for research involving human beings were complied with. The women who agreed to participate in the study signed the Informed Consent Term (Of. 453/08 - CEP).

The author responsible for test collection informed the women about the test results and all SW with an STD diagnosed in this study were immediately treated, in those cases covered by the Botucatu Municipal Health Secretary Women's Health Protocol, or were forwarded for medical treatment at the Primary Health Care referral unit.

\section{Results}

The characteristics of the 102 SW under analysis reveals that these are young adult women, with a mean age of 26.1 years. A majority had nine or more years of education $(53.0 \%)$, was single $(71.6 \%)$ and mentioned their first sexual intercourse before the age of 15 years (59.8\%).

STD prevalence in the SW under analysis was $71.6 \%$ (73 cases).

HPV was the most frequent agent (45.1\%) when considered in isolation and, when considering mixed infections, CT and HPV (15.6\%). No cases of infection by Neisseria gonorrhoeae or hepatitis B were diagnosed. No isolated cases of TV occurred either, with associated prevalence corresponding to $3.0 \%$. HIV was detected in $1.0 \%$ of the SW (Table 1 ).

Table 1 - Prevalence of sexually transmitted diseases, isolated or associated, in 102 sex workers under analysis. Botucatu, Brazil, 2009

\begin{tabular}{|c|c|c|}
\hline STD & No & $\%$ \\
\hline $\mathrm{HPV}^{*}$ & 46 & 45.1 \\
\hline $\mathrm{CT}^{\dagger}$ & 3 & 2.9 \\
\hline Syphilis & 1 & 1.0 \\
\hline \multicolumn{3}{|l|}{ Mixed Infections } \\
\hline $\mathrm{HPV}^{*}+\mathrm{CT}^{\dagger}$ & 16 & 15.6 \\
\hline $\mathrm{HPV}^{*}+\mathrm{TV}^{\ddagger}$ & 2 & 2.0 \\
\hline Syphilis + HPV* & 2 & 2.0 \\
\hline $\mathrm{HPV}^{*}+\mathrm{CT}^{\dagger}+\mathrm{TV}^{\ddagger}$ & 1 & 1.0 \\
\hline Syphilis + HPV* $+\mathrm{CT}^{\dagger}$ & 1 & 1.0 \\
\hline $\mathrm{HPV}^{*}+\mathrm{HIV}^{\S}$ & 1 & 1.0 \\
\hline
\end{tabular}

Sixty-nine $(67.6 \%)$ of the women under analysis tested positively for HPV.

The main genotype identified was 16 , corresponding to $24.6 \%$ in isolation and $8.6 \%$ when considering associations (Table 2). 
Table 2 - Type of HPV genotype detected in 69 sex workers under analysis. Botucatu, Brazil, 2009

\begin{tabular}{lcc}
\hline \multicolumn{1}{r}{ Type of Genotype } & No & $\%$ \\
\hline 16 & 17 & 24.6 \\
33 & 6 & 8.7 \\
18 and 33 & 4 & 5.8 \\
$6 / 11,16$ and 33 & 4 & 5.8 \\
$6 / 11$ and 33 & 2 & 2.9 \\
16,18 and 33 & 1 & 1.4 \\
16 and 33 & 1 & 1.4 \\
Others & 34 & 49.3 \\
\hline
\end{tabular}

\section{Discussion}

Local data are presented about the prevalence of STD in the population of female sex workers from a medium interior city in São Paulo State, which can represent a reference for other cities and contribute to the STD prevention policy in São Paulo State. Although the theme is not new, it was the first study performed in Botucatu and Regional Health Department-VI, including 68 cities near Botucatu. One limitation, however, was HPV genotyping, as the technique used, specific-primer$P C R$, needs positive controls for its reaction and only controls $6 / 11,16,18,33$ and 45 were available at the laboratory where the study was performed. Another additional technique, such as gene sequencing, would be needed to elucidate the genotypes of the $31.4 \%$ of HPV detected in the cervical material samples and not identified through PCR.

The general prevalence of STD among the SW under analysis was high: $71.6 \%$, in which the isolated or associated occurrence of HPV (45.1\% and $22.6 \%$, respectively) and $\mathrm{CT}(2.9 \%$ and $17.6 \%$, respectively) should be highlighted. The general prevalence, including associations, of syphilis $(4.0 \%)$ and trichomoniasis $(3.0 \%)$ should also be emphasized, as well as the occurrence of one case of HIV (1.0\%) and the inexistence of gonorrhea and Hepatitis B in the study population.

The comparison between these data and those obtained from other Brazilian studies is not simple, due to the range of existing diagnostic tests and the fact that many of these studies do not cover the same STD included in the present research, which only used gold-standard diagnostic tests. To permit discussion, the collected data were compared with the general female population and SW or other vulnerable groups. Only studies were mentioned that also used gold-standard tests, however.

The prevalence of HPV (67.7\%) was much higher than findings in gynecology outpatient clinics in São Paulo
$(16 \%)^{(9)}$. Considering genotyping, $50.7 \%$ of patients positive for HPV presented at least one genotype of high oncogenic risk. The prevalence of highly oncogenic HPV in the present study was similar to findings in a group of SW from Belgium, where $77.4 \%$ tested positively for one or more types of HPV, $55.9 \%$ of which for highly oncogenic HPV(10).

Cervical cancer is the most frequently diagnosed among Southern Vietnamese women, where incidence levels figure among the highest in the world. Among 282 SW living in this area, the DNA of HPV was detected in $85 \%$ of them, without any variation in prevalence levels according to age. Thirty-five HPV genotypes were detected, with 52 as the most common type. Half of HPV-positive women were infected with oncogenic types and $37 \%$ with multiple genotypes ${ }^{(11)}$.

The prevalence of CT was $20.5 \%$, close to findings in a Brazilian study carried out at an STD clinic in

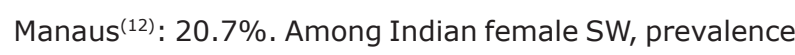
levels were lower though, amounting to $7.8 \%$ among brothel workers ${ }^{(13)}$. In Guatemala, after an intervention, prevalence decreased from $10.7 \%$ to $6.2 \%{ }^{(5)}$. It should be highlighted that this infection has been associated with early age of first sexual intercourse ${ }^{(14)}$.

Regarding TV, the level (3.0\%) was lower than findings at a gynecology clinic in Brasília, where prevalence corresponded to $4.8 \%{ }^{(15)}$, and among Indian SW, with a prevalence level of $5.9 \%{ }^{(16)}$.

In this study, the syphilis prevalence level (4.0\%), was higher than what was found in Umuarama/PR, in a study from 2008: $2.7 \%{ }^{(17)}$ and lower than findings from international studies. In China(18), India(19) and Guatemala(5), studies involving SW found prevalence levels of $11.0 \%, 6.6 \%$ and $8.6 \%$ after an intervention, respectively.

A prevalence level of $1.0 \%$ of HIV was found, below findings in a study carried out in Umuarama/PR ${ }^{(17)}$ and China $^{(18)}: 2.7 \%$ and $2.3 \%$, respectively. In Madagascar, Africa(14), however, none of the SW presented HIV.

Like in the abovementioned African country ${ }^{(14)}$, no case of gonorrhea was identified in this research when using culture in Tayer Martin medium for diagnosis. Quite varying prevalence levels of this cervicitis are found in scientific literature: $6.4 \%$ after an intervention involving SW in Guatemala(5) and $16.9 \%$ among SW from Surat City, India(20).

No case of Hepatitis B was identified either, against a prevalence of $2.7 \%$ in SW from Paraná(17). A study involving immigrant SW in Madrid, Spain found a prevalence of $3.5 \%$ for this disease ${ }^{(21)}$ and, in a recent Indian study involving SW, prevalence amounted to $3.3 \%{ }^{(19)}$. 
Summarizing the discussed prevalence picture, it can be affirmed that, in general, the high STD rates among SW from Botucatu was due to the occurrence of HPV, although there were few comparable Brazilian studies. Generally speaking, the situation of other STD in this city was better or at least equal to findings from different studies, not only among SW, but also in other more or less vulnerable population groups, such as people who attended an STD clinic and a gynecology outpatient clinic.

This picture cannot be considered positive, as twothirds of the women had some STD. The situation of HPV and $\mathrm{CT}$ is particularly concerning.

The fact that HPV infection is known as one of the most prevalent and incident STD in the world(22) does not minimize the problem, especially due to the high prevalence of high-risk genotypes. In addition, $31.4 \%$ of genotypes were not characterized in this study, for which high risk cannot be discarded. The lack of symptoms and routine screening makes this a public health problem, due to the great dissemination of the virus.

Regarding $\mathrm{CT}$, the strong impact on women is related to the fact that it facilitates HIV infection, can trigger an ascending infection in the female genital tract, which can lead to endometritis, salpingitis, tubo-ovarian abscesses and peritonitis, of different severity levels, sometimes causing death ${ }^{(23)}$. It should also be highlighted that, once caught, this infection can continue for months, enhancing a long dissemination period, aggravated by the lack of routine screening and asymptomatic course, which may remain unnoticed even during clinical exams(24), which also contributes to turn this infection into a public health problem.

Due to the high prevalence of STD, some actions can be suggested with a view to this population's individual health promotion: stimulating the adoption of healthy practices, such as condom use in all sexual relations. The need to guarantee this population's access to public health services should also be considered, as well as adequate professional training for contact with this group of women, attempting to get to know their reality, without prejudices, with a view to better care delivery.

A study carried out in Benim, Africa showed that, during a six-year intervention period (1993-1999): prevalence levels of several STD decreased: HIV from $53.3 \%$ to $40.6 \%$; syphilis from $8.9 \%$ to $1.5 \%$ and gonorrhea from $43.2 \%$ to $20.5 \%$, concluding that interventions can exert a positive influence, resulting in the decreased prevalence of these diseases ${ }^{(25)}$. Thus, interventions are suggested aimed at SW in the studied city.

\section{Final considerations}

The prevalence of STD in the SW under analysis was high, with HPV as the most frequent isolated agent. When considering mixed infections, the main association identified was between CT and HPV and HPV genotype analysis evidenced that 16 was the most frequent genotype. No isolated cases of TV occurred and its associated prevalence corresponded to $3.0 \%$. HIV was detected in $1.0 \%$ of the women studied. No case of Neisseria gonorrhoeae or hepatitis B was identified.

This study can support health action planning aimed at SW. It can also support the elaboration of an STD profile diagnosis in the most vulnerable groups in São Paulo State and Brazil, where research on this theme still are not very frequent. Moreover, it can contribute to break the transmission chain of these diseases.

\section{References}

1. Ministério da Saúde (BR). Secretaria de Vigilância em Saúde. Programa Nacional de DST e Aids. Manual de bolso das doenças sexualmente transmissíveis. Brasília (DF): Ministério da Saúde; 2006. 111 p.

2. World Health Organization. Department of HIV/AIDS. Global prevalence and incidence of selected curable sexually transmitted infections [internet]. 2001 [acesso 20 jan 2010] Disponível em: http://www.who.int/ docstore/hiv/GRSTI/003.htm.

3. Aquino PS, Nicolau AIO, Moura ERF, Pinheiro AKB. Perfil sociodemográfico e comportamento sexual de prostitutas de Fortaleza - CE. Texto Contexto Enferm. $2008 ; 17(3): 427-34$.

4. Ministério da Saúde (BR). Secretaria de Políticas de Saúde. Coordenação Nacional de DST e Aids. Profissionais do sexo: documento referencial para ações de prevenção das DST e da aids. Brasília (DF): Ministério da Saúde; 2002. 160 p.

5. Sabidó M, Giardina F, Hernández G, Fernández VH, Mozon JE, Ortiz R, et al. The UALE Project: Decline in the incidence of HIV and sexually transmitted infections and increase in the use of condoms among sex workers in Guatemala. J Acquir Inmune Defic Syndr. 2009;51 Suppl $1: 35-41$.

6. Dessunti EM, Reis AOA. Psychosocial and behavioral factors associated to STD/AIDS risk among health students. Rev. Latino-Am. Enfermagem. 2007;15(2):267-74.

7. Possas CA. Apresentação. Rev Saúde Pública. 2007;41 Suppl 2:3. 
8. Guimarães K, Merchán-Hamann E. Comercializando fantasias: a representação social da prostituição, dilemas da profissão e a construção da cidadania. Estud Fem. 2005; 13(3):320.

9. Nonenmacher B, Breitenbach V, Villa LL, Prolla JC, Bozzetti MC. Identificação do papilomavírus humano por biologia molecular em mulheres asintomáticas. Rev Saúde Pública. 2002;36(1):95-100.

10. Mak R, Van Renterghem L, Cuvelier C. Cervical smears and human papillomavirus typing in sex worker. Sex Transm Infect. 2004;80(2):118-20.

11. Hernandez B, Nguyen TV. Cervical human papillomavirus infection among female sex workers in southern Vietnam. Infect Agent Cancer. 2008;3:7.

12. Santos C, Teixeira F, Vicente A, Astolfi-Filho S. Detection of Clamydia trachomatis in endocervical smears of sexually active women in Manaus-AM, Brazil, by PCR. Braz J Infect Dis. 2003;7(2):91-5.

13. Buzdugan R, Copas A, Moses S, Blanchard J, Isac S, Ramiesh BM, et al. Devising a female sex work typology using data from Karnataka, India. Int J Epidemiol. 2010;39(2): 439-48.

14. Harijaona V, Ramambason JD, Morisset R, Rasamindrakotroka A, Ravaoarinoro M. Prevalence of and risk factors for sexually-transmitted infections in hidden female sex workers. Med Mal Infect. 2009;39(12):90913

15. Lobo TT, Feijo G, Carvalho JE, Costa PL, Chagas C, Xavier $\mathrm{J}$ et al. A comparative evaluation of the papanicolaou test for the diagnosis of trich omoniasis. Sex Transm Dis. 2003;30(9):694-9.

16. Divekar AA, Gogate AS, Shivkar LK, Gogate S, Badhwar VR. Disease prevalence in women attending the STD clinic in Mumbai (formerly Bombay), India. Int J STD AIDS. 2000;11(1):45-8.

17. Correa NAB, Matumoto FH, Lonardoni MVC. Doenças sexualmente transmissíveis em mulheres profissionais do sexo, Umuarama, Estado do Paraná. RBAC. 2008;40(3):209-13.

18. Lu F, Jia Y, Sun X, Wang L, Liu W, Xiao Y, et al. Prevalence of HIV infection and predictors for syphilis infection among female sex workers in southern China. Southeast Asian J Trop Med Public Health. 2009;40(2):263-72.

19. Shethwala ND, Mulla SA, Kosanbiya JK, Desai VK. Sexually transmitted infections and reproductive tract infections in female sex workers. Indian J Pat Microbiol. 2009; 52(2):198-9.
20. Thakor HG, Kosambiya JK, Umrigar DN, Desai VK. Prevalence of sexually transmitted infections in sex workers of Surat City. Indian J Comm Med. 2004;29(3):104-8.

21. Gutiérrez $M$, Tajada $P$, Alvarez $A$, De Julian $R$, Baquero $M$, Soriano $V$, et al. Prevalence of HIV-1 non-B subtypes, syphilis, HTLV, and hepatitis B and C viruses among immigrant sex workers in Madrid, Spain. J Med Virol. 2004;74(4):521-7.

22. Magi JC, Brito EMS, Grecco ETO, Pereira SMM, Formiga GJS. Prevalência de Papilomavírus Humano (HPV) anal, genital e oral, em ambulatório geral de coloproctologia. Rev Bras Coloproctol. 2006;26(3):233-8.

23. CDC Centers for Disease Control and Prevention. Guidelines for treatment of sexually transmitted diseases. Morb Mortal Wkly Rep. 2002;51:1-80.

24. Marques CAS, Menezes MLB. Infecção genital por Clamydia trachomatis e esterilidade. J Bras Doenças Sex Transm. 2005;17(1):66-70.

25. Alary M, Mukenge-Tshibaka L, Bernier F, Geraldo N, Lowndes CM, Meda $\mathrm{H}$, et al. Decline in the prevalence of HIV and sexually transmitted diseases among female sex workers in Cotonou, Benin, 1993-1999. AIDS. 2002;16(3):463-70.
Received: Feb. $22^{\text {nd }} 2010$ Accepted: Mar. 10 2011 